\title{
The Real (Social) Experience of Monetary Policy*
} Sheila C Dow

A contribution to G Harcourt and J Pixley (eds), Financial crises and the nature of capitalist money: Mutual developments from the work of Geoffrey Ingham. London: Palgrave Macmillan.

\begin{abstract}
This paper takes a socio-economic approach to considering money in relation to real experience, focusing on the real effects of monetary policy. While most of the economics literature focuses on interest-rate setting as the core tool of monetary policy, we focus here instead on signalling by the central bank as a mechanism for influencing expectations and behaviour in conditions of uncertainty. This involves addressing the social-conventional expectations among different groups (a mechanism for dealing with uncertainty) applied to their particular ways of framing the real and financial sectors. Actual credit conditions faced by borrowers in turn are the outcome of the conventional view among banks as a result of their framing and the influence of central bank signalling. These relations between central banks, banks and the non-bank public in turn normally rest on long-established relations of trust. We consider the real effects of monetary policy in circumstances where trust has broken down.

*This chapter has benefited from helpful comments from Victoria Chick, Daniela Gabor, Geoff Harcourt, Alberto Montagnoli and Jocelyn Pixley.
\end{abstract}

\author{
SCEME \\ Division of Economics \\ University of Stirling \\ Stirling FK9 4LA \\ Scotland, UK \\ Tel: +44-1786-467474 \\ Fax: +44-1786-467469 \\ e-mail: s.c.dow@stir.ac.uk
}

August 2012 


\section{Introduction}

Economists increasingly acknowledge the social aspect of economic life. It has become commonplace, even in mainstream economics, to make reference to Adam Smith's Theory of Moral Sentiments, for example. But the implications of taking on board the significance of social processes for economic outcomes are potentially profound. In considering the effects of monetary policy, the social aspects of human knowledge and of the nature of money are of particular importance. Yet only in non-mainstream economics is sociality taken seriously enough to influence the approach to theorising. It is well established now that mainstream economics rests on methodological individualism whereby sociality is treated as a modification to the preferences of and constraints on atomistic individuals, rather than something which is built into the foundations (see, for example, Davis 2003).

A critique of this mainstream economics approach when applied to money has been the focus of Geoffrey Ingham's contribution to monetary theory. His remarkable achievement has been to bring together the fields of sociology and economics in his analysis of the nature of money. As an economist, I cannot speak to the implications for sociology, but the implications for economics are far-reaching. By exploring the different ontologies of money in the mainstream approach to theory and in his alternative social theory, Ingham (2004) demonstrates how they feed into theory and policy and thus reality. His work has had a profound influence on the non-mainstream theory of money.

For Ingham, money is a social relation which arises out of debt contracts and thus reflects a balance of power relations in society. While Ingham shares the emphasis on the role of the state in these power relations associated with chartalism ${ }^{1}$, he goes further in 
focusing on the role of power with respect to knowledge. What constitutes reality is itself the outcome of power relations, such that knowledge is performative. In the absence of 'true' knowledge, how we understand reality is subject to a variety of influences which are primarily social and/or political. Whatever this understanding of reality is in turn influences real outcomes. Credit decisions are based on assessments of future risks and returns which are based on a particular framing (including an underlying theoretical approach to interpreting economic developments), a particular set of institutional arrangements and a particular configuration of economic power. ${ }^{2}$ The importance for the eurozone of the institutional arrangements agreed in Maastricht is a clear example. The outcome of such power relations (among governments and banks in relation to the real economy) is a level and distribution of credit which in turn influences real experience.

The purpose of this chapter is to explore these ideas further in the context of monetary policy. While Ingham focused on the nature of money, he also drew implications for monetary policy on which we will build. We explore first what money is, and then what monetary policy means in relation to money as a social relation - how it influences the social relation. We are then in a position to consider the consequences of monetary policy for real (social) experience. While our understanding of experience is mediated by particular framings, nevertheless we adopt the realist position that there is something which we can recognise as real experience.

\section{The meaning of money}

In order to explore the meaning of monetary policy we start by reviewing the nature of money itself. As Ingham (2004, ch. 1) explains, the mainstream view of money is based 
on a commodity exchange view of money, which can be analysed in a conventional supply-demand framework in the same way as any other commodity. Of course, this has caused logical difficulties in that it is not clear what services money provides in equilibrium (the benchmark state for all of mainstream theory and the universal state for the influential rational expectations approach). Equilibrium is a state where no more trades take place. ${ }^{3}$ The only explanation for holding money which holds some logic in this framework is the notion of a buffer stock of liquidity to meet transactions requirements when economic outcomes can only be predicted within a probability distribution.

But the commodity notion of money was inadequate even when money was primarily a commodity, that is, made from precious metals. As Ingham explains, the value of coins was influenced as much by the degree of authority associated with the sovereign's stamp and the confidence in the coins' value in exchange. Once bank notes became accepted as money, their value also reflected the degree of confidence in the ability of the issuer, whether the state or private banks, to redeem notes in coin. Now that the overwhelming bulk of what is regarded as money takes the form of bank deposits (redeemable normally in notes issued by the central bank ${ }^{4}$ ), their value depends on the general state of confidence in the banking system. This includes the regulation and supervision of commercial banks by the authorities and the system in place should such regulation and supervision fail to prevent a bank having trouble meeting its commitments.

How far bank deposits serve as money therefore depends on social relations, between the state, the banking system and the non-bank public, as well as between the 
banks themselves and the non-bank public. Money's social role is to provide the basis for contracts, including borrowing and lending (Davidson 2002), to provide a safe haven in times of turbulence and to denominate and facilitate transactions. All of these functions require that money's value is regarded as stable relative to alternative assets. Following Keynes, Ingham identifies the unit of account function as key to the nature of money: a commodity used in exchange is only money if it is representative of a unit of account, that is, it represents abstract value. This definition of money is historically anterior to markets, an argument supported by Heinsohn and Steiger's work ${ }^{5}$ (see further Goodhart, 2003).

The social relations which underpin a successful banking system take time and experience to build up (see Chick 1986 and chapter 8 of this volume). But the nature of the social relations which constitute money changes as the form of money changes. While commodity money is the closest to being a pure asset ('outside money'), it still involves an element of 'moneyness' from being issued by the state; seignorage is the counterpart to this moneyness which effectively provides credit to the state. Once banks issue notes and, later in history, deposit entries against which cheques can be issued, they are the direct consequence and counterpart of credit. Not only is the confidence in the value of money then dependent on confidence in the soundness of the bank's balance sheet (a social relation) but also the nature of money itself arises from the social relation of credit. Credit in turn is the outcome of valuations of risk and return, and the confidence in such valuations, which arise from conventional knowledge about the borrowers and power relations between borrowers and the banks, involving further social relations. The core of Ingham's position is that money is a social relation. 


\section{The meaning of monetary policy}

Inevitably how we understand money will determine how we view monetary policy. In mainstream theory monetary policy focuses on the money stock and the official interest rate at which the central bank provides liquidity to the banks (using mechanisms which have evolved through different institutional arrangements). ${ }^{6}$ Money's primary role is seen as being to facilitate transactions. It is understood not to have any consequences in the long run other than to determine the price level (it is 'neutral' in the long run). The goal of monetary policy has therefore increasingly been seen as being to control the price level, often put explicitly in the form of an inflation target. The theoretical justification is expressed in terms of the rational optimising decision-making of atomistic individuals. The demand for money at any time is understood as representing the aggregation of the outcome of all these individual decisions while its supply is understood to be under the control of the central bank. In practice it proved to be difficult to control the money supply, so the official interest rate became the policy instrument, as an indirect means of controlling the money supply. If the interest rate is seen as the price of money and the demand for money is a stable function of the rate of interest, then it makes no difference in this framework which is chosen as the instrument. ${ }^{7}$ But the move away from expressing monetary policy in terms of the money supply has meant that 'the relationship between the orthodox conception of money in economic analysis and practical monetary policy is now tenuous to the point of incoherence' (Ingham, 2004, p. 9; see further chapter 7). 
The idea of announcing money supply targets, and then inflation targets, was understood within mainstream theory principally as a means to assist the private sector in forming expectations. Apparent deviations from money's long-term neutrality meant that it was accepted that monetary policy could have real consequences in the short run as producers and households mistakenly adjusted their expenditure plans and workers suffered from money illusion (not realising the consequences of monetary policy for inflation). The more the public's expectations were aligned to the target path for the money supply or inflation, the less likely they would be to mistake monetary developments for real developments.

This push for transparency first arose from rational expectations theory. But the emerging focus on impediments to the proper functioning of free markets within New Keynesian theory added particular force to this approach to policy. ${ }^{8}$ For New Keynesians asymmetric information is a fundamental issue, explaining the financial crisis, for example, as the result of different parties concealing risk information from each other. As New Keynesian theory gained in influence, the push for transparency was extended beyond announcing targets to explaining the thinking behind policy decisions. 'Signalling' has therefore now become a major plank of monetary policy, with much care going into publications, speeches and press conferences (Geraats, 2002; Dow, Klaes and Montagnoli, 2007).

This emphasis on transparency as a means of enhancing expectations formation might appear to hold something in common with the view of money as a social relation, with an emphasis on information. Preda (2007), for example, sees information as a common thread in the sociological theory of financial markets. But the premise of the 
mainstream approach is that the economic system is such that risk is quantifiable and that there is therefore such a thing as a true price. Mainstream economic theory presumes the future to be knowable, at least within a probability distribution. Asymmetric information is thus simply a matter of concealing information; transparency is designed to mitigate that, particularly with respect to openness about central bank thinking.

But the non-mainstream view of the economic system is that it is open and evolving, through institutional change and through agency as well as through social conventions. Such a system cannot yield certain knowledge (including certain knowledge of risk). The general case is therefore that knowledge is uncertain. Uncertainty increases during periods of marked instability, but its pervasiveness in human experience has required the evolution of such institutions as monetary systems and also of coping mechanisms in the necessary practice of expectations formation. Reliance is therefore placed on conventional knowledge which is built up among different groupings according to their own framings and conventions. ${ }^{9}$ It is through its influence on these framings and conventions that the central bank conducts monetary policy. This influence in turn reflects influence on the central bank both of political processes and also of power within the private sector, notably the financial sector. But since money and monetary policy involve a balance of social and political forces it is to be expected that instability rather than equilibrium will be the outcome (Ingham, 2004, p. 14).

Traditionally, monetary policy has been conducted through open market operations - the buying and selling of government bonds in order to drive long-term interest rates in a particular direction. Increasingly monetary policy focused on short-term interest rates, through the setting of an official rate in the repo market and its enforcement 
through open market operations. ${ }^{10}$ Central banks are now also trying to influence long rates by quantitative easing - the buying of (mostly) government debt leading directly or indirectly to additions to banks' balances with the central bank.

Central banks can have a significant impact on financial markets simply because they are such large players and thus their transactions have particular influence on market expectations. But it is the fact that such actions signal the intent of monetary policy which makes them potentially so influential. But, while signalling in the mainstream approach is simply a matter of revealing information, the non-mainstream approach sees signalling as embedded in the particular framing of monetary policy adopted by policy-makers. More generally, the reality of information generation in the financial sector is such that framing (the way in which information is understood) is critical to outcomes. The central bank not only employs its own framing but also goes further in trying to ensure that others understand policy in the same way. The central bank thus seeks to increase its persuasiveness by creating an 'epistemic community' with the aim both of depoliticising monetary policy and of imposing the central bank's own framing on other groupings (Ingham, 2004, p. 146). By using a rhetoric which presents quantitative easing in monetarist terms as a significant expansionary push, for example, central banks depict the situation as one in which it would be appropriate for banks to expand lending. The policy impasse can therefore be understood as the result of a confrontation between this framing and the reality of banks' real experience in the credit market as they understand it (quite apart from the way potential borrowers understand it). The outcome of monetary policy can thus be understood as itself being a social relation - the outcome of a negotiated struggle between different power groupings, each with its own framing. 
Forder (2006) traces the way in which monetarist framing has pervaded the monetary policy discourse in the UK, while Gabor (2011) takes a discourse approach to an analysis of the framing of monetary policy in Romania. Drawing on communications theory, Pigeon (2008) develops the mechanisms by which conventional framings are established and propagated. He explores in detail for Canada the build-up over decades of the mechanisms used to persuade along these lines, ranging from the form taken by consultation and communication to the choice of words and metaphors employed. For monetary policy he emphasises the efforts made to foster a common framing of inflation targeting by means of a common use of language among the different groupings. The rhetoric implies that central banks are being transparent with respect to a stock of information which it is politically and economically optimal to share. But the gulf between theory and practice in monetary policy is evident in the arguments (particularly from central banks) against being literally transparent where knowledge is held with uncertainty and monetary policy requires judgement (see, for example, Eusepi, 2005).

This way of understanding signalling (other than as literal transparency) fits well with Pixley's (2012) analysis of the role of emotion in behaviour in the financial sector under uncertainty. She argues that much depends on trust, between all parties. Trust in turn depends on successful mechanisms by which confidence is built up in expectations about future actions. This in turn requires a shared framing of the policy problem and its solutions. As she argues (Pixley, 2012, pp. 222 and 241), the Libor issue highlights the importance of trust or lack of trust among the banks. In particular, the central bank may deliberately suppress transparency in order to maintain trust. Confidence involves a noncalculative set of expectations which can be eroded when a particular understanding of 
the monetary system is challenged by events, as in the banking crisis. Framings are not independent of experience, but rather mediate it. However, the experience of crisis which erodes confidence turns the issue into one of trust in the agency of banks and central banks (Hughes, 2011). The challenge for central banks is to persuade the public to accept an understanding of the situation whereby central bank actions can be trusted. Where shared understandings along these lines are not achieved, conflicting framings persist and trust is not restored.

In the next section we turn to considering the different framings of the real social effects of monetary policy.

\section{The consequences of monetary policy for real (social) experience}

\section{Conventional non-neutrality}

In mainstream theory, the effects of monetary policy are captured in one or more transmission mechanisms. (There has been disagreement about the precise nature of these mechanisms.) The Bank of England Monetary Policy Committee (1999), involved in the practice of monetary policy, sets out a range of mechanisms. But the outcome of the transmission is the effect on inflation, since that is the variable to which monetary policy is directed within this approach. This representation of the role of modern monetary policy is in sharp contrast to the view taken in the UK in the late 1950s in the Radcliffe Report (Committee on the Working of the Monetary System, 1959). Here a range of goals was identified, the first being a high and stable level of employment, and the inevitable scope for potential conflicts between all the goals were accepted and explored. 
Monetarist theory, which underpinned UK monetary policy from 1979, identified the transmission of an expansionary policy in the spending of new excess money balances on assets or goods and services (or the inducement to do so by reduced interest rates if that is the policy tool), while a contractionary policy would correspondingly induce reduced expenditure. If the starting point was full employment equilibrium, the end result would be a rise or fall in inflation, respectively. Now that there is a fear of not meeting the inflation target because aggregate demand is too weak, the same analysis is currently being employed to explain the policy of quantitative easing (Bank of England, 2012b).

But as mainstream theory developed in the $1980 \mathrm{~s}$ in the form of rational expectations theory, the aim was to channel the transmission as directly as possible into expected inflation, in order to minimise short-run changes in expenditure and employment (short-run non-neutrality). The New Keynesian focus on transparency adds further force to this aim to use monetary policy to influence expectations directly. ${ }^{11}$ The benchmark of long-run full employment equilibrium continues to condition the mainstream view of monetary policy as being addressed to controlling inflation. The aim is for monetary policy not to affect real experience.

But the actual transmission of monetary policy to aggregate demand (via expectations) is being inhibited by weak bank lending. In the current conditions central banks are clearly having difficulty in exerting influence on banks, either directly through the official rate or indirectly through signalling. Banks have been setting high and variable mark-ups on the official rate and have been slow to increase lending. This provided the rationale for quantitative easing. But this policy is not having the desired 
effect of increasing credit. There is a lack both of demand for credit and of supply because of weak aggregate demand and a high degree of uncertainty combined with dimmed animal spirits. But in any case non-mainstream endogenous money theory points out that the means by which central banks enforce their official rate is to manage the supply of liquidity. Except in times of crisis, had banks wanted more liquidity at the official rate, central banks would have supplied it anyway. ${ }^{12}$ You cannot push on a string.

Even where governments have substantial ownership of commercial banks, as in the UK at present, monetary policy is not having the desired effect. While efforts continue to influence expectations such that the official interest rate will steer the economy along a full employment course at 2 per cent inflation, with no real effects, actual interest rates continue to diverge from the official rate. Measures, such as the 'funding for lending' scheme in the UK (Bank of England, 2012a), have therefore been introduced as a financial inducement to banks to increase lending at reduced rates.

It is becoming increasingly tenuous to justify monetary policy in mainstream terms of individualistic rational optimising decision making with respect to information which, if not known, is knowable. The focus, derived from monetarism, on the money stock as the variable which monetary policy addresses (even if indirectly, through interest rates) is clearly divorced from real experience. Attention has shifted back to credit (as the stumbling block in attempts to manipulate the money supply and thus aggregate demand). But the credit market is framed in the mainstream terms of independent supply and demand curves, expressed in terms of price (lending rates). The rhetoric of quantitative easing retains the old assumption of an exogenous money supply, whereby monetary aggregates are determined as a multiple of the monetary base which quantitative easing is 
designed to expand. The relevance of default risk is understood (due to the influence of New Keynesian credit-rationing theory). But, since there is a presumption that this risk can be measured objectively (even if concealed from lenders), the analysis may proceed in terms of supply and demand with respect to creditworthy borrowers. The effect of monetary policy is then the effect on rational choice of a change in price (interest rate). Yet the concern is that uncertainty is inhibiting rational choice with respect to both the supply of and demand for credit. But uncertainty has no place in the theory.

The non-mainstream view of money identifies the non-neutrality of money, but also of monetary policy, at different levels. Considering non-neutrality in the mainstream sense of affecting output and employment, Post-Keynesian theory, for example, sees the potential for monetary policy to affect these variables, that is, to affect real experience, even in the long run. The channels through which this may occur are the effect of the changing availability of credit and the effect of changing interest rates on plans to invest and to consume at a time of less-than-full employment. Monetary policy has its effect on the credit decisions of banks and borrowers and the resulting changes in expenditure, output and employment. But the volume of credit is the outcome of commercial bank decisions, and banks acquire the necessary reserves through the money market. Central banks sustain their official interest rate by means of supplying additional liquidity to the money market as required, such that the supply of reserves is endogenous to banks' credit policy. The transmission of monetary policy is thus primarily through the credit market.

This transmission can occur through a range of channels, given the interdependence between different asset markets. But without the Efficient Markets Hypothesis, heterodox economists take account of segmentation in financial markets. 
Monetary policy can aim to influence different interest rates, through central bank purchase or sale of different types and maturities of assets. Thus, for example, the policy of quantitative easing in the UK included purchase of corporate bonds in an attempt directly to ease the funding of investment. ${ }^{13}$ But small and medium-sized enterprises (SMEs) generally do not have access to the capital market and do not have well-funded treasury departments. They thus depend heavily on bank finance, and monetary policy can be addressed to influencing the rate banks charge on loans and also banks' willingness to lend. This can be done by manipulating the official rate, but variable markups demonstrate the limited power of the central bank to determine loan rates. Rather the main influence is exercised through central bank communications designed to influence the expectations of banks and borrowers about future financial conditions and the future state of the economy. Increased bank lending to SMEs facilitates increased production and employment and thereby influences real experience. Similarly real household experience of consumption and housing is influenced by the cost and availability of consumer loans and mortgage loans, respectively. Conversely, a withdrawal of banks from lending can lead to bankruptcy, unemployment, reduced consumption and foreclosures on mortgages, all potentially causing some kind of real hardship. Central bank attempts to address these issues conflict with the efficient-markets narrative which has framed so much of their previous policy stance. ${ }^{14}$

The above argument has much in common with the mainstream framework, especially New Keynesian theory, which emphasises the credit channel (because of SME dependency on bank lending) and which allows for unemployment due to market imperfections (especially information asymmetries). But the non-neutrality of money in 
non-mainstream theory also applies at a different, more fundamental, level. We proceed to explore the implications for additional real effects of monetary policy which arise because of money being a social relation. We focus on the two senses in which money is a social relation: the social framework of credit as it affects banks' credit strategies on the one hand and the trust in money based in experience of the operations of the state and the banking system as a whole on the other hand. Both are important for how monetary policy affects real experience. We address each in turn.

\section{Non-conventional non-neutrality I: credit as a social relation}

Within a non-mainstream framework supply and demand for credit are interdependent because of the shared significance of uncertainty with respect to expectations. Thus Minsky (1975) showed the supply of credit contracting when lender's risk increased and the demand for credit contracting when borrower's risk increased. Since it is the short end of the market which dominates, it is bank perceptions which are more important when there is unsatisfied demand for credit. Perceptions of these risks may differ, but in times of high uncertainty they are subject to common influences. But monetary policy in the form of promoting a particular framing of the economic situation actively promotes a shared conventional understanding of expected risk and return, and thus increased interdependence between supply and demand. It is therefore common, as now, in weak economic conditions for low credit growth to prompt accusations that banks are unduly restricting the availability of credit. But it is equally common for such accusations to be countered by the argument that demand for credit is weak. Both banks and potential borrowers are expressing their strong liquidity preference in reducing both supply of and 
demand for credit. The outcome is continued weakening in output and employment and living standards.

The real experience of the credit market itself is a negotiation between borrower and lender, each framing the decision according to their own judgements and neither with objective knowledge of default risk. The decision cannot be rational in the mainstream sense, given uncertainty: reason applied to knowledge must be supplemented by conventional opinion and by emotion (Pixley, 2012; Dow, 2011). Further the negotiation depends on the relative power of the parties concerned - whether the borrower is a large multinational company or a small start-up, for example. Monetary policy, as we have seen, involves signalling with respect to central bank analysis and intentions. But, in a non-mainstream framework, it also involves efforts to frame economic conditions in a particular way. This framing feeds through into the credit decision.

An example is provided by the regional finance literature. The mainstream portion of this literature frames financial markets as equilibrating, such that banks distribute credit (subject to the volume of reserves as determined by the central bank) to regions with the highest marginal productivity of capital, thus promoting regional economic convergence. The regional impact of monetary policy is thus not considered any further than the sectoral impact. The Post-Keynesian literature, on the other hand, sees bank credit as endogenously determined by the banking system and created in different regions according to conventional understandings of region-specific risk and return. But SME borrowers in peripheral regions are little understood by banks located in big financial centres. Relatively high uncertainty discourages lending to them. Yet, given the weak knowledge base, events such as natural resource discovery in such regions can 
dramatically change the way in which these economies are framed, encouraging substantial capital inflows. But, given the weak knowledge base, these flows are vulnerable to sudden reversals, which have a devastating effect on financially vulnerable

regions. ${ }^{15}$ Given this vulnerability, monetary policy will have an exaggerated effect on peripheral economies (see Dow and Rodriguez Fuentes, 2003; Dow and Montagnoli, 2007). The more regional credit is administered by local financial institutions with a framing of risk and return which is built on real experience, the more protected are peripheral economies from credit volatility. Removing regional (or indeed other) segmentation from financial markets, in contrast, can promote economic divergence rather than convergence, as in the EU (Chick and Dow, 2012).

\section{Non-conventional non-neutrality II: money as a social relation}

But if money itself, as the outcome of credit decisions, is a social relation, then money is non-neutral in an even more fundamental way. Money forms the basis for all sorts of other social relations, such as contracts, denomination of wealth and exchange. But what acts as money is itself a social relation; there is a social convention underpinning the identification of particular assets as money. This is something which evolves with experience and with the institutional arrangements by which money is issued. Thus the modern dominance of bank deposits as money is the result of a long history of the evolution of banking and its relationship with the state. The framing which reflects confidence in banks has a clear social basis, since in rationalist terms the basis of confidence is weak. Fractional-reserve banking means that, in the event of a bank run, banks cannot conceivably meet all their obligations to redeem deposits in notes and coin. 
It is confidence in the institutional framework and the agency of the authorities to prevent the incidence of bank runs which overrides such considerations. This traditional role of central banks which evolved from the experience of bank runs (or the threat of runs) in the past reflected an appreciation of the crucial role of money. Without money, a capitalist form of economic organisation is inconceivable (Dillard, 1987). Money can have no more powerful role to play in real social experience.

In normal times, monetary policy is not seen as impacting on this role of money. Mainstream theory of monetary policy is addressed to inflation, which could be seen as ensuring that national money continues to perform its function. Inflation erodes the storeof-value function of money. But, because equilibrium theory is unable to explain money's full socioeconomic role (far less its function as a store of value), the justification for controlling inflation tends either to be rather tortuous or to appeal to the very different considerations of the distributional effects on borrowers and lenders.

But the banking crisis has brought to the surface the whole issue of the degree of society's confidence in money. If there is a real or perceived risk of banks going bankrupt, then depositors start to focus on whether or not these deposits are indeed a good store of value. Inflation recedes into the background as the primary focus of monetary policy in times of crisis and attention turns to ensuring the viability of the banking system itself. Indeed where the banking crisis has been compounded by a fiscal crisis, the viability of the state itself has been open to question (evidenced in the escalation of yields on sovereign debt). The very fact that questions are raised about bank viability punctures the conventional confidence which had been built up over centuries of experience with banks and their relationship with the state. Hence the tremendous 
potency of visual media images of queues outside the UK's Northern Rock bank branches in 2007 .

Central banks have been acting to rebuild confidence in the banking system by discussing proposals for regulatory change, some of which have the potential to impact on borrowers' experience (restrictions on mortgage loans for example). But shorter-term policies such as quantitative easing, which are partly designed to improve bank balance sheets, are having little impact on the cost and availability of credit. The emphasis otherwise has been on signalling in the broad sense of framing the problem in a particular way. Thus, for example, central banks have focused on the shortcomings of banks, /with their 'too big to fail' recourse to the lender-of-last-resort facility, as the cause of the banking crisis. Banks are depicted as having succumbed to moral hazard. This taps effectively into the public concern with bankers' remuneration and the focus on agency when trust breaks down (Hughes, 2011). Yet the lender-of-last-resort facility had emerged as part of an arrangement between banks and the central bank whereby banks were supported in their endeavours to supply society's money in exchange for regulation and supervision. But the process of deregulation which had proceeded from the 1970s allowed banks to be exposed to ever higher and ever more opaque risks at the same time as increasing in scale, such that most became too big to fail because of the impact that such failure would have on socioeconomic relations. Not only had banks gone back on the deal, but so had central banks. Central banks' focus on the moral hazard of banks constructed a narrative which distracted attention from their own moral hazard. Indeed, the moral hazard has been the danger of a breakdown in social relations (Dow, 2012). 


\section{Conclusion}

Money functions as a social relation based on conventional practices and attitudes. We have seen how the banking crisis has eroded confidence in bank-issued money, and even in the state itself. The uncertainty which has resulted has had profound real effects. Because of a high degree of uncertainty, firms are unwilling to invest, households are unwilling to spend. Banks, companies and households seek liquidity. The resulting recession worsens the public sector finances. Because these finances are framed by a mainstream economics approach which promotes budgetary balance, the resulting policy is fiscal austerity, which in turn worsens the deficit. Where successful, government rhetoric persuades society that this short-term pain is justified by the long-term gain. But fiscal austerity erodes the role of the state in providing social services, at a time when income distribution is becoming ever more polarized.

While mainstream theory subsumes uncertainty in quantifiable risk, it has been impossible to ignore uncertainty in public discourse. But the way in which it is understood is framed by the theoretical approach used. Thus, just as emotions are treated as random disturbances to outcomes generated by rationally optimising individuals, so uncertainty is treated as a random shock. Yet the two are intimately connected (Pixley, 2012). In Post-Keynesian economic theory, uncertainty is endemic and underlines the social role of money as a refuge from uncertainty.

Mainstream theory of monetary policy approaches the question of the real effects of monetary policy in terms of short-term non-neutrality as a result of market imperfections, notably information asymmetries. Monetary policy is now addressed as much to aligning expectations with a mainstream framing of policy and its effects, such 
that the real effects of policy are minimised, as to manipulating interest rates and the money supply. As policy confronts real experience, however, the incoherence of this approach is exposed and alternative measures are sought to improve real experience.

The non-mainstream approach has explained the long-term non-neutrality of money and monetary policy in standard Keynesian terms. But here we have focused on more fundamental aspects of money's non-neutrality, which arises from its nature as a social relation. From this follows a more fundamental non-neutrality of monetary policy. This has become particularly evident in the banking crisis, where the social relations underpinning money are threatened.

These are extraordinary times. They follow the 'great moderation' and the 'new consensus' on monetary policy, whereby there was a dominant narrative among mainstream theorists and policy-makers. An epistemic community had been created such that monetary policy was understood as a technical matter designed not to have real consequences. Public confidence was such that monetary policy did not attract significant critical attention. The central bank narrative dominated, not least because it supported the interests of the financial sector.

But the crisis drove a wedge between the interests of the financial sector, the central bank and the public. Further, the central bank narrative had been based on an assumption of financial stability which was clearly at odds with the real experience of financial markets. Critical attention was therefore increasingly focused on central bank actions and their impact on that real experience. New monetary policy measures have thus been introduced, which were often at odds with the way in which the role of monetary policy continued to be framed. Central banks have adapted their practice in the 
face of real experience, but continue to apply a traditional (monetarist) framing which banks refuse to accept (that an injection of reserves should translate into new lending). Conflict therefore continues between central banks' efforts to increase bank lending on the one hand and the banks' understanding of the risks involved in such lending on the other hand. The non-bank public's understanding of their own experience of financial vulnerability, in turn, has put a critical focus on the banks, such that policy with respect to banks is now an important political issue. The framings of different groups in society are evolving in themselves and in relation to each other in an ongoing process of negotiation. The signs are there that monetary policy too is a social relation.

\section{References}

Bank of England (2012a) 'The Funding for Lending Scheme: Explanatory Note', http://www.bankofengland.co.uk/markets/Pages/FLS/default.aspx.

Bank of England (2012b) 'Quantitative Easing Explained', http://www.bankofengland.co.uk/monetarypolicy/Pages/qe/default.aspx accessed 17 July 2012.

Bank of England Monetary Policy Committee (1999) The Transmission Mechanism of Monetary Policy. London: Bank of England.

Chick, V. (1983) Macroeconomics After Keynes. Oxford: Philip Allan and Cambridge, MA: MIT Press. 
Chick, V. (1986) 'The Evolution of the Banking System and the Theory of Saving, Investment and Interest', Economies et Sociétés, Cahiers de l'ISMEA, Série 'Monnaie et Production', No. 3, pp. 111-26. Reprinted in P. Arestis and S. C. Dow (eds), On Money, Method and Keynes: Selected Essays by Victoria Chick. London: Macmillan, 1992.

Chick, V. and Dow, S. C. (2012) 'On Causes and Outcomes of the European Crisis: Ideas, Institutions and Reality', Contributions to Political Economy, 31 (1), pp. 51-66.

Committee on the Working of the Monetary System (1959) Report. London: HMSO. (The 'Radcliffe Report').

Davidson, P. (2002) Financial Markets, Money and the Real World. Cheltenham, UK and Northampton, MA, USA: Edward Elgar.

Davis, J. B. (2003) The Theory of the Individual in Economics: Identity and Values. London: Routledge.

Dillard, D. (1987) 'Money as an Institution of Capitalism', Journal of Economic Issues, 21, $1623-47$.

Dow, S. C. (2011) 'Cognition, Sentiment and Financial Instability: Psychology in a Minsky Framework', Cambridge Journal of Economics 35(2), pp. 233-50.

Dow, S. C. (2012) 'What are Banks and Bank Regulation For? A Consideration of the Foundations for Reform', Intervention, 9 (1), pp. 39-56. 
Dow, S. C. (forthcoming) 'Framing Financial Markets: A Methodological Approach', in Oostwouder, W and Schenk, H. (eds), Governance of the Modern Firm under Financial Turbulence, Cheltenham: Edward Elgar.

Dow, S. C., Klaes, M. and Montagnoli, A. (2007) 'Monetary Policy by Signal', in D. G. Mayes and J. Toporowski (eds), Open Market Operations and the Financial Markets. London: Routledge, pp. 334-51.

Dow, S. C. and Montagnoli, A. (2007) 'The Regional Transmission of UK Monetary Policy', Regional Studies 41(6), pp. 797-808.

Dow, S. C. and Rodriguez Fuentes, C. (2003) 'EMU and the Regional Impact of Monetary Policy', Regional Studies 37(9), pp. 969-80.

Eusepi, S. (2005) 'Central bank transparency under model uncertainty', Federal Reserve Bank of New York Staff Reports, No. 199, January.

Forder, J. (2006) 'Monetary Policy', in P. Arestis and M. Sawyer (eds), A Handbook of Alternative Monetary Economics. Cheltenham: Edward Elgar, pp. 224-41.

Gabor, D. (2011) Central Banking and Financialization: A Romanian Account of how Eastern Europe became Subprime. London: Palgrave Macmillan.

Gabor, D. (2012) 'Learning from Japan: The ECB's unconventional monetary policy', University of the West of England Working Paper, http://papers.ssrn.com/sol3/papers.cfm?abstract_id=2172416

Geraats, P. M. (2002) ‘Central bank transparency’, Economic Journal, 112, F532-65. 
Goodhart, C A E (1998) 'The two concepts of money: implications for the analysis of optimal currency areas', European Journal of Political Economy 14 (3): 407-32.

Goodhart, C. A. E. (2003) 'The two concepts of money: Implications for the analysis of optimal currency areas', in S. A. Bell and E. J. Nell (eds), The State, the Market and the Euro, Cheltenham: Edward Elgar, pp. 15-29.

Goodhart, C. A. E. (2007) 'Monetary and Social Relationships', in A. Gioacom and M. C. Marcuzzo (eds), Money and Markets: A Doctrinal Approach. London: Routledge, pp. $15-29$.

Heinsohn and Steiger, O. (2006) 'Interest and Money: the property explanation', in P. Arestis and M. Sawyer (eds), A Handbook of Alternative Monetary Economics. Cheltenham: Edward Elgar, pp. 490-507.

Hughes, P. (2011) Trust: Economic Notions and its Role in Money and Banking, University of Stirling PhD thesis.

Ingham, G. (2000) “'Babylonian madness': on the historical and sociological origins of money', in J. Smithin (ed.), What is Money? London: Routledge, pp. 16-41.

Ingham, G. (2004) The Nature of Money. Cambridge: Polity.

Minsky, H. P. (1975) John Maynard Keynes. London: Macmillan. 
Niebyl, K. H. (1946) Studies in the Classical Theory of Money. New York: Columbia University Press.

Pigeon, M. A. J. (2008) Conflict, Consensus, Convention: The Depoliticization of Canada's Macroeconomic Discourse, Carleton University PhD thesis.

Pixley, J (2012) Emotions in Finance: Booms, Busts and Uncertainty, 2nd edition. Cambridge: Cambridge University Press.

Poole, W. (1970) 'Optimal choice of policy instruments in a simple stochastic macro model', Quarterly Journal of Economics, 84, pp. 197-216.

Preda, A. (2007) 'The Sociological Approach to Financial Markets', Journal of Economic Surveys, 21(3), pp. 506-28.

Smith, A ([1759] 1976) The Theory of Moral Sentiments, edited by D D Raphael and A L Macfie. Oxford: Clarendon.

1 See Goodhart (1998) for a discussion of chartalism.

${ }^{2}$ This approach to money echoes that of Niebyl (1946) in his analysis of classical monetary theory, where he identified a dialectical process of influence from real experience to ideas to policy to real experience and so on, all mediated by power relations.

${ }^{3}$ See Chick's (1983, pp. 213-18) critique of Tobin's monetary theory along these lines. 
${ }^{4}$ There are exceptions, as in Scotland and Northern Ireland, where deposits with private banks are redeemable in their own notes and where central-bank-issued notes are not legal tender. See http://www.bankofengland.co.uk/banknotes/Pages/about/scottish_northernireland.aspx.

${ }^{5}$ See for example Heinsohn and Steiger (2006) for a recent account.

${ }^{6}$ See Goodhart (2007) for a more full account of the evolution of the mainstream theory of monetary policy, and Gabor (forthcoming) for its use in rationalising different policy measures.

${ }^{7}$ Since the underlying relations were understood to be stochastic, it could nevertheless be significant for the outcome of monetary policy which had the higher variance. Thus the choice between the money supply and the interest rate as the policy instrument would depend on the particular specification of the IS and LM curves (see Poole, 1970).

${ }^{8}$ Politics were also important for the move to transparency. Pigeon (2008) explores the political factors influencing the rise of transparency in fiscal as well as monetary policy in Canada.

${ }^{9}$ See Dow (forthcoming) for a socioeconomic discussion of framing with respect to financial markets.

10 The repo rate is the rate at which the central bank supplies liquidity by buying assets from banks subject to an agreement by the banks to repurchase them at a specified price after a set period (such as two weeks). 
${ }^{11}$ To the extent that New Keynesians identify non-neutrality of money in the short run, it is a result of credit rationing. The argument is that borrowers conceal true risk from lenders, who then use the rule of thumb that it is better to restrict availability of credit by rationing than to raise interest rates, which would encourage more risk-taking by borrowers.

12 The extreme case of the banking crisis beginning in 2007 was such that the interbank market through which the central bank enforces the official rate actually froze, requiring proactive supply of liquidity by central banks.

${ }^{13}$ In practice the bulk of quantitative easing has occurred in the sovereign debt market.

${ }^{14}$ See Gabor (2012) for an account of the different crisis measures adopted by Japan and the ECB and their theoretical justifications.

15 The South East Asia crisis in 1997 provides an exemplar of this phenomenon, whereby massive capital inflows based on very limited knowledge were suddenly reversed. Pixley (2012) documents more recent behaviour by German banks along these lines, even after the onset of crisis in 2007. 